\title{
The influence of sensitivity for road traffic noise on residential location: Does it trigger a process of spatial selection?
}

\author{
Hans A. Nijland ${ }^{a)}$ \\ Netherlands Environmental Assessment Agency, Bilthoven, Utrecht 3720BA the Netherlands \\ Sander Hartemink \\ Faculty of Geographical sciences, Utrecht University, Utrecht, the Netherlands \\ Irene van Kamp \\ National Institute for Public Health and the Environment, RIVM, Bilthoven, the Netherlands \\ Bert van Wee \\ Faculty of Technology, Policy and Management, Delft University of Technology, Delft, the Netherlands
}

(Received 25 September 2006; revised 27 February 2007; accepted 20 June 2007)

\begin{abstract}
People move to another house for different reasons. It is sometimes presumed that a process of self-selection might take place on the basis of noise sensitivity, i.e., sensitive people would either leave high noise areas or not move into these areas in the first place. Thus, a "survivor population" would remain in the high noise areas. This research aims to investigate whether such a process can be observed in the Netherlands. The study does not show evidence of a process of self-selection based on noise sensitivity. Nevertheless, the results suggest that noise-sensitive people are less satisfied with their living environment and are more willing to move than those who are not noise sensitive. Due to the limited sample size, external validity is limited. (C) 2007 Acoustical Society of America. [DOI: 10.1121/1.2756970]
\end{abstract}

PACS number(s): 43.50.Qp [BSF] Pages: 1595-1601

\section{INTRODUCTION}

Yearly, about $10 \%$ of the Dutch population (i.e., 1.6 million people) moves to another dwelling (Ekamper and Van Huis, 2002). This percentage has been more or less constant since 1946, when Statistics Netherlands started to collect yearly figures (www.cbs.nl/nl/cijfers/statline).

This article will concentrate on the role of noise sensitivity as one of the reasons for people to move to a quiet area, or, in contrast, one of the reasons not to move into a noisy neighborhood in the first place. The outcome of the analysis should provide an answer to the question: does a process of self-selection due to road traffic noise on the basis of noise sensitivity exist? To date, very little research has focused on a self-selection process due to noise sensitivity and road traffic noise. Lako (1987) analyzed the relationship between road traffic noise and migration in a sample of 3000 dwelling units, divided in a high exposure area and a low exposure area. Unfortunately, he did not pay attention to the possible influence of noise sensitivity. This research aims to fill that gap by investigating the impact of noise sensitivity on residential location. Researchers discern a change in the household, in work, in education and dissatisfaction with the dwelling and/or the neighborhood as main reasons to move to another location. (e.g. Clark, 1982; Owen, 1992; Clark et al., 1996, 1999; Mulder and Hooijmeijer, 1999; Gardner et al., 2001; Housing Corporation, 2004). Literature reports relatively few environmental factors such as noise levels or

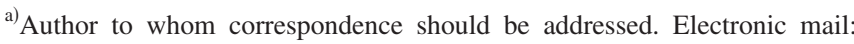
hans.nijland@mnp.nl
}

concentrations of pollutants as main reason for moving (Rohrmann 1986, 1991). Leidelmeijer and Marsman (2001) found around 5\% of the people in the area of Schiphol definitely wanting to move within two years mainly for environmental reasons. They mentioned noise as the most important stressor.

Noise sensitivity is often defined as a stable, personal trait, influencing one's reaction to noise, independent of the noise level (Zimmer and Ellermeier, 1999, Ellermeier et al., 2001). The association between noise sensitivity and noise exposure is consistently low (Job, 1988). Research showed that noise sensitivity is a major antecedent of noise annoyance (see Taylor 1984; Stansfeld et al., 1985; Stansfeld 1992, Job 1988; 1999; Staples 1996; van Kamp et al., 2004). Job (1988) found noise sensitivity to explain $10.2 \%$ of the variation in noise annoyance reactions. Noise sensitivity is associated with health variables such as sleep disturbance (Ohrstrom, 1995) and psychological distress and psychiatric disorders (Stansfeld, 1992, Stansfeld et al., 1985, 1993, 1996).

Figure 1 presents a conceptual model of the role of noise and noise sensitivity in the process of moving. It shows the main reasons for moving and it illustrates that the process of moving is a multi-stage decision process (as already described by Rossi, 1955). It also shows that noise sensitivity (in combination with noise level) plays a role in the different stages of that process, when moving out and when moving in.

Job (1988) and Fields (1992) hypothesized that people in high noise areas could be abnormally tolerant of high noise because of a process of self-selection, i.e., sensitive 


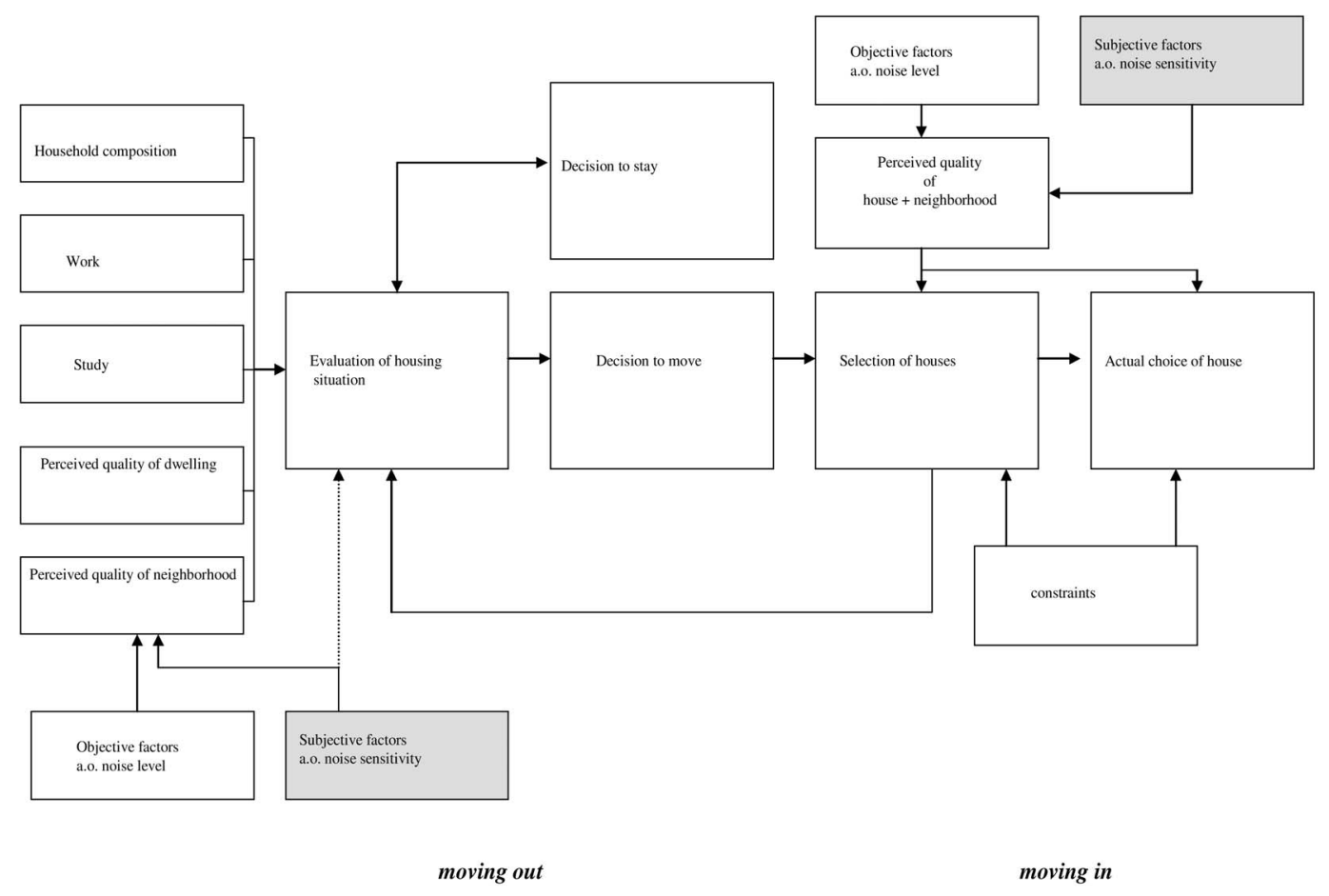

FIG. 1. Conceptual model of moving houses and the role of noise and noise sensitivity in that process.

people would either leave high noise areas or not move into the areas initially. However, in his meta-analysis, Fields did not find conclusive evidence to support this theory.

The outcome of our research might not only be of scientific interest. If such a process of self-selection exists, it might have consequences for the estimated levels of annoyance in the case of new infrastructure. It would mean that annoyance of the people affected, based on average population responses, is usually underestimated in the short and medium term, because in quiet areas an overrepresentation of noise-sensitive people might be expected. In the (very) long term, after all dwellings had new inhabitants, the new population would consist mainly of people relatively insensitive to noise. Thus, in the very long term, annoyance, again based on average population responses, would be overestimated.

\section{NOISE ANNOYANCE AND NOISE SENSITIVITY}

Noise is an environmental problem that has adverse effects on the daily life of many people. Exposure to noise, in combination with nonacoustical factors, determines the effects of noise on the health and well being of humans. Table I shows the effects of noise, the respective threshold levels and typical situations in which those effects occur. The values in $\mathrm{dB}(\mathrm{A})$ represent the levels above which effects occur.

It has been estimated that around $20 \%$ of the European Union's population, close to 80 million people, suffer from noise levels that scientists and health experts consider to be unacceptable. At these levels most people become annoyed, sleep is disturbed and adverse health effects are to be feared. An additional 170 million people are living in so-called "gray areas," where the noise levels are high enough to cause serious annoyance during the daytime (European Commission, 1996). Traffic, especially road traffic, is the main cause of noise.

The noise level is but one of the factors influencing people's reactions on noise. It is estimated that about a third of the individual variety of responses to noise can be explained

TABLE I. Health effects and respective threshold levels for exposure, Source: Dutch Health Council, Noise and Health, 1994.

\begin{tabular}{lcccc}
\hline \hline & & \multicolumn{3}{c}{ Noise exposure threshold level } \\
\hline & Situation & Noise index & $\begin{array}{c}\text { Guideline value } \\
\text { in dB(A) }\end{array}$ & Inside/outside \\
- Hearing impairment & Work & $L_{\text {Aeq }}, 24 \mathrm{~h}$ & 70 & Inside/outside \\
- High blood pressure & Work & $L_{\text {Aeq }}, 8 \mathrm{~h}$ & $<85$ & Inside \\
& Home & $L_{\text {Aeq }}, 6-22 \mathrm{~h}$ & 70 & Outside \\
- Ischaemic heart diseases & Home & & & \\
- Serious annoyance & Home & $L_{\mathrm{dn}}$ & 55 & Outside \\
- Awakening & Sleep & & 30 & Inside \\
- Sleep disturbance & Sleep & $L_{\text {Aeq }}, 8 \mathrm{~h}$ & & Inside \\
- Poor self-reported quality of sleep & Sleep & & & Inside \\
- Negative performance at school & School & $L_{\text {Aeq }}$, day & 35 & \\
\hline \hline
\end{tabular}

Adjusted according to recommendations of the Dutch Health Council of 1997. This was formerly 60. 
by nonacoustical factors (Guski et al., 1978; Job, 1988; Guski, 1999; Höger 1999; Flindell and Stallen, 1999; Stallen, 1999). The nonacoustical factors are often categorized in personal and in situational or contextual factors (Guski 1987, Fields 1993). Situational factors may have no apparent relationship to noise, like, e.g., the visual attractiveness of the neighborhood. Research showed that people's reactions to noise are influenced by aesthetic aspects of the neighborhood (Langdon, 1976; Kastka and Noack, 1987). Other situational factors concern the overall context in which noise is perceived and assessed (Blauert 1990, Lévy-Leboyer and Moser, 1987). The personal factors can be distinguished in demographic (sex, age, household size, education, occupational status, home ownership, dependency of the source) and attitudinal factors (fear, noise sensitivity).

The largest difference in annoyance due to demographic factors is caused by age, equivalent to a difference of noise exposure of up to $5 \mathrm{~dB}(\mathrm{~A})$, where the middle-aged group (30-50) is most annoyed at the same noise level (Fields 1992, Miedema 1999). The other demographic factors are less relevant and may account for differences equal to maximum 1-2 dB(A).

The main nonacoustical factors influencing the individual responses to noise are the attitudinal ones: fear of the source, sensitivity to noise and the possibility of controlling the noise (Fields, 1992). The effect of noise sensitivity is equivalent to a difference in noise exposure of $11 \mathrm{~dB}(\mathrm{~A})$ (Miedema and Vos, 1999).

\section{METHODS}

To answer the question whether self-selection due to noise sensitivity exists, we conducted a case study at Maarssenbroek, a suburb in the western part of the Netherlands built in the 1970s and 80s. We chose that suburb for two reasons. First, the clear gradation in noise levels from road traffic gave people the choice for settling for a quieter or noisier living environment. Second, the dwellings of Maarssenbroek are more or less of the same type (fairly uniform single-family dwellings), which means that choosing a quieter environment does not automatically imply choosing a very different type of dwelling or neighborhood. The confounding influence of differences in socio-economic status was minimized as much as possible by choosing this kind of suburb.

In Maarssenbroek, dwellings are predominantly privately owned and families are typically middle class. Very high and very low incomes are rare. Maarssenbroek has approximately 9000 households and 25,000 inhabitants (CBS, 2003). The average income in Maarssenbroek (11.300 Euro/year) is slightly above Dutch average (11.000 euro/year). Average household size in Maarssenbroek (2.6) is slightly bigger and younger than Dutch average (2.3).

Maarssenbroek is located next to one of the major motorways (around 150,000 cars and lorries pass every day, AVV 2003). Noise screens were constructed simultaneously with the construction of the suburb itself. This excludes the disturbing effect of significant reductions in noise levels after the residential choice of some of the respondents. We chose two sample areas, one close to the highway, one at some distance. Noise loads at the dwellings close to the highway were around $65 \mathrm{~dB}(\mathrm{~A}) L_{\mathrm{den}}$, we will call this the high exposure area. Noise loads in the other area, further away, were $50-55 \mathrm{~dB}(\mathrm{~A}) L_{\mathrm{den}}$. We will call this the low exposure area. The noise levels were ascertained from (calculated) noise maps (Milieudienst Noord-West Nederland, 2000) as well as from our own measurements. A total of 300 households in the low (150) and in the high (150) exposure areas were randomly selected. A questionnaire was sent to the 300 households. The response rate was $67 \%$; the most cited reasons for nonresponse were lack of time or lack of interest in the neighborhood. As compared to Maarssenbroek as a whole, single-person households were slightly underrepresented in our survey, whereas households with children were slightly overrepresented (see Table II).

The survey concentrated on noise sensitivity, noise annoyance, neighborhood (dis)satisfaction and willingness to migrate. Socio-economic and demographic variables were included as well, because they are known to be related to noise sensitivity and annoyance levels (see Sec. II).

Noise sensitivity can be measured by different questionnaires. Most broadly used are the 1-item, the 10-item (Zimmer and Ellermeier, 1998a, 1998b) and the 21-item (Weinstein 1978) questionnaire. The 10- and the 21-item questionnaires have been shown to have satisfactory predictive validity in field research (e.g., Weinstein, 1978; Topf, 1985, Zimmer and Ellermeier 1999). In this research, the 10 -item version was used to measure individual noise sensitivity. We used the 1-item test only to see whether people were able to valuate their own noise sensitivity (see Discussion).

No threshold score for noise sensitivity is known from literature. Here we considered people to be sensitive to noise, if they had scored 72 points or more (of maximum 100 points) on the Noise Sensitivity Scale. We chose this value to be in line with the threshold value for noise annoyance (Miedema et al., 2001). We analyzed other threshold values (the $10 \%$ and $50 \%$ most noise-sensitive ones vs. the $10 \%$ and $50 \%$ least sensitive ones). It did not really change the results of the next paragraph.

\section{RESULTS}

Around $24 \%$ of the respondents were highly annoyed by roadway noise. Table II shows that significantly $(P<0.001)$ more highly annoyed people live in the high exposure area as compared to the low exposure area. In our research, noise exposure therefore correlates positively with noise annoyance, as is already extensively known from the literature (e.g. Miedema et al., 2001). In both the high and the low exposure areas, around $23 \%$ of the population is sensitive to noise.

There was no significant relation between noise exposure and noise sensitivity, and this remained unchanged after adjustment for potential confounders (age, gender, length of residency, size of household, education level and income). In fact, adjustment only contributes to a slight increase in variability (see Table III). 
TABLE II. Survey figures compared to those for the population of Maarssenbroek.

\begin{tabular}{|c|c|c|c|c|c|}
\hline \multirow[b]{2}{*}{ Highly annoyed } & & \multirow{2}{*}{$\begin{array}{l}\text { Survey total } \\
(N=200) \\
24 \% \\
(N=48)\end{array}$} & \multirow{2}{*}{$\begin{array}{l}\text { Survey } \\
\text { low } \\
\text { exposure } \\
(N=93) \\
3 \% \\
(N=3)\end{array}$} & \multirow{2}{*}{$\begin{array}{l}\text { Survey high } \\
\text { exposure } \\
(N=107) \\
42 \% \\
(N=45)\end{array}$} & \multirow[t]{2}{*}{$\begin{array}{c}\text { Maarssenbroek } \\
\text { (source: CBS 2003) }\end{array}$} \\
\hline & & & & & \\
\hline Noise sensitive & & $\begin{array}{l}24 \% \\
(N=47)\end{array}$ & $\begin{array}{l}24 \% \\
(N=22)\end{array}$ & $\begin{array}{l}23 \% \\
(N=25)\end{array}$ & \\
\hline \multirow[t]{3}{*}{$\begin{array}{l}\text { Composition of } \\
\text { household }\end{array}$} & $\begin{array}{l}\text { Single } \\
\text { person }\end{array}$ & $\begin{array}{l}10 \% \\
(N=20)\end{array}$ & $\begin{array}{l}10 \% \\
(N=9)\end{array}$ & $\begin{array}{l}11 \% \\
(N=11)\end{array}$ & $23 \%$ \\
\hline & No children & $\begin{array}{l}25 \% \\
(N=49)\end{array}$ & $\begin{array}{l}17 \% \\
(N=16)\end{array}$ & $\begin{array}{l}33 \% \\
(N=33)\end{array}$ & $27 \%$ \\
\hline & $\begin{array}{l}\text { With } \\
\text { children }\end{array}$ & $\begin{array}{l}64 \% \\
(N=125)\end{array}$ & $\begin{array}{l}73 \% \\
(N=67)\end{array}$ & $\begin{array}{l}57 \% \\
(N=58)\end{array}$ & $50 \%$ \\
\hline \multirow[t]{4}{*}{ Age } & $18-24$ & $\begin{array}{l}1 \% \\
(N=1)\end{array}$ & $\begin{array}{l}1 \% \\
(N=1)\end{array}$ & $\begin{array}{l}0 \% \\
(N=0)\end{array}$ & $12 \%$ \\
\hline & $25-44$ & $\begin{array}{l}36 \% \\
(N=69)\end{array}$ & $\begin{array}{l}34 \% \\
(N=31)\end{array}$ & $\begin{array}{l}38 \% \\
(N=38)\end{array}$ & $46 \%$ \\
\hline & $45-64$ & $\begin{array}{l}58 \% \\
(N=110)\end{array}$ & $\begin{array}{l}59 \% \\
(N=53)\end{array}$ & $\begin{array}{l}57 \% \\
(N=57)\end{array}$ & $35 \%$ \\
\hline & $>64$ & $\begin{array}{l}5 \% \\
(N=10)_{-}\end{array}$ & $5 \%(N=5)$ & $5 \%(N=5)$ & $7 \%$ \\
\hline \multirow[t]{2}{*}{ Gender } & Woman & $\begin{array}{l}52 \% \\
(N=104)\end{array}$ & $\begin{array}{l}59 \% \\
(N=55)\end{array}$ & $\begin{array}{l}46 \% \\
(N=49)\end{array}$ & $51 \%$ \\
\hline & Man & $\begin{array}{l}48 \% \\
(N=96)\end{array}$ & $\begin{array}{l}41 \% \\
(N=38)\end{array}$ & $\begin{array}{l}54 \% \\
(N=58)\end{array}$ & $49 \%$ \\
\hline \multirow[t]{3}{*}{$\begin{array}{l}\text { Length of } \\
\text { residency (years) }\end{array}$} & $0-5$ & $\begin{array}{l}11 \% \\
(N=20)\end{array}$ & $\begin{array}{l}14 \% \\
(N=12)\end{array}$ & $\begin{array}{l}8 \% \\
(N=8)\end{array}$ & \\
\hline & $6-10$ & $\begin{array}{l}7 \% \\
(N=13)\end{array}$ & $\begin{array}{l}7 \% \\
(N=6)\end{array}$ & $\begin{array}{l}7 \% \\
(N=7)\end{array}$ & \\
\hline & $>10$ & $\begin{array}{l}82 \% \\
(N=155)\end{array}$ & $\begin{array}{l}80 \% \\
(N=70)\end{array}$ & $\begin{array}{l}85 \% \\
(N=85)\end{array}$ & \\
\hline
\end{tabular}

Thirty-five percent of the noise-sensitive people were highly annoyed by roadway noise against only $20 \%$ of the noise-insensitive people. Similarly, $42 \%$ of the people in the high exposure area and 3\% in the low exposure area were annoyed by noise. Table IV shows that relatively more noisesensitive people are highly annoyed compared to the not noise-sensitive group. The effect on noise annoyance of the combination of the acoustical factor noise exposure and the nonacoustical factor noise sensitivity is extremely small. Whereas noise exposure alone explains $32 \%$ of the variety of individual responses, and noise sensitivity alone explains $3 \%$, the combination of these two factors explains $36 \%$ of the variety of individual responses.

The survey contained several questions on (dis)satisfaction with the dwelling and the neighborhood and on the desire to move. Analyzing the satisfaction with the dwelling and the neighborhood by noise-sensitive and not noisesensitive people by means of the Fisher's Exact Test showed significant differences between the two groups: i.e., the noise-sensitive group members were significantly less satisfied with their dwelling $(P=0.003)$ and their living environment $(P=0.009)$ than the noise-insensitive ones, in the high noise area as well as in the low noise area. The survey showed that there was no significant difference in desire to move between people in high noise and in low noise areas $(P=0.44)$. At the same time there was a significant difference in desire to move between sensitive and not sensitive ones $(P=0.008)$. Noise-sensitive people are nearly twice as likely to want to move than those who are not sensitive $(40 \%$ against $21 \%)$. No interaction was found between noise sensitivity, noise exposure and desire to move $(P=0.91)$

\section{CONCLUSIONS AND DISCUSSION}

Our main conclusions are first that we found no relationship between noise sensitivity and noise exposure. This re-

TABLE III. Logistic regression model of the relation between noise sensitivity and noise exposure $(N=200)$.

\begin{tabular}{lcl}
\hline \hline & $\begin{array}{l}\text { Odds ratio (95\% CI) high } \\
\text { exposure, unadjusted }\end{array}$ & $\begin{array}{l}\text { Odds ratio (95\% CI) high } \\
\text { exposure, } \\
\text { adjusted for potential } \\
\text { confounders }^{\mathrm{a}}\end{array}$ \\
\hline High level on sensitivity scale & $1.01(0.49-2.08)$ & $1.08(0.50-2.37)$ \\
\hline \hline
\end{tabular}

age, gender, length of residency, children at home, education level and income 
TABLE IV. Percentage of people highly annoyed by road traffic noise in high and low exposure areas (Chisquare $p<0.001$ ).

\begin{tabular}{lll}
\hline \hline & High exposure $(N=107)$ & Low exposure $(N=93)$ \\
\hline Noise sensitive $(N=47)$ & $60 \%(N=15)$ & $9 \%(N=2)$ \\
Not noise sensitive $(N=153)$ & $37 \%(N=30)$ & $1 \%(N=1)$ \\
\hline \hline
\end{tabular}

mained unchanged after adjustment for potential confounders. Therefore, our research did not show any evidence of a process of self-selection based upon noise sensitivity. However, it did show, secondly, that people who are noise sensitive tend to be less satisfied with their dwelling and their neighborhood than those who are not sensitive to noise. The noise-sensitive people think more often about moving elsewhere.

Our research suggests that noise sensitivity is not a major factor in the process of moving and settling down, at least not where road traffic is the major noise source. These findings are in line with the research of Babisch (presented in Prague, 2004). Other factors related to the dwelling or the neighborhood probably play a more important role, as shown by recent research on factors influencing the process of moving in the Netherlands by Van de Griendt (2004). He found that of all environmental factors, soil pollution is the major concern among potential buyers of dwellings. No doubt, this has to do with the large financial consequences of soil pollution for home owners. Noise only played a minor role in the final decision on which home to buy. These findings are confirmed by the field studies available so far (SchümerKohrs and Schümer, 1974; Michelson, 1980; Rohrmann, 1991). These studies indicate that significant weight is put on noise exposure among the principal considerations. Yet noise exposure has only moderate influence on actual moving or residential choice.

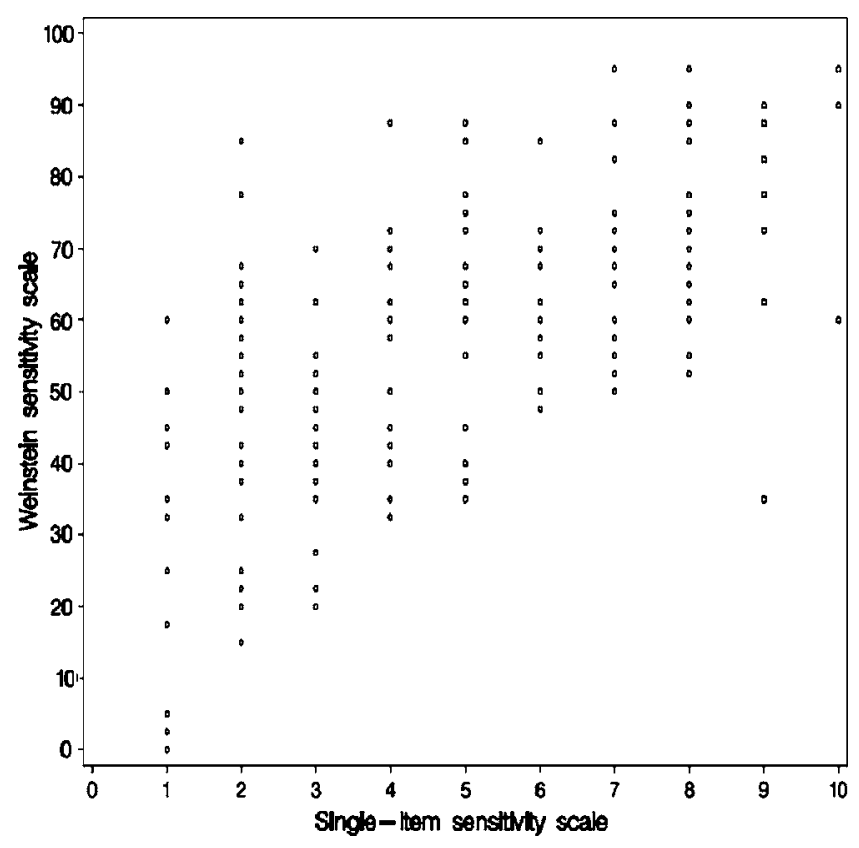

FIG. 2. Individual scores on two tests for noise sensitivity, i.e., the 1-item and 10 -item tests.
Due to the cross-sectional character and the limited sample size, we could not distinguish between the role of noise sensitivity in the separate processes of moving out and moving in (see Fig. 1). To do so, either a longitudinal survey and/or a far bigger sample size is required.

In our research, we distinguished areas with high and low noise levels. We did not consider other environmental factors like odor, air pollution or vibrations that are associated with proximity to the highway as well. In future research, it may be worthwhile to pay more attention to these potential confounders.

Noise-sensitive people in our research were less satisfied with their dwelling and their living environment than those who were not noise sensitive. This is in line with research of Miedema and Vos (2003) who found indications for a general negative attitude among noise-sensitive people.

Assuming that people often act more or less rationally, one might ask: why is it (as in our case) that people who are sensitive to noise deliberately move into high exposure areas? Isn't this asking for trouble? One explanation might be that people are simply not aware that they are noise sensitive. This explanation is supported by the fact that the Weinstein 10-item test, generally regarded as a good indicator of noise sensitivity, is only weakly correlated to the 1-item test, in which people directly answer the question whether they regard themselves to be noise sensitive or not. According to the distribution-free Spearman's rank correlation test, both test results show a positive, but rather weak correlation; Spearman rho is 0.629 at 0.01 level; for a strong correlation the outcome would at least have to be above 0.8. See Fig. 2).

A second explanation, as sometimes found in literature (e.g., Zimmer and Ellermeier, 1999), could be that noise sensitivity increases with length of residency. One could hypothesize that the noise-sensitive people in the high exposure area were not noise sensitive at the time of moving in but became so during their residency. Analysis of the data in our research did not show a correlation between noise sensitivity and length of residency though.

Another explanation might lie in the tight market for dwellings, especially in the western part of the Netherlands. Potential home buyers may have a long list of criteria on which to base their decision and the noise level may be just one of those criteria. In practice, given the tight housing market, no dwelling will meet all the criteria and the final decision is usually based on a compromise in which noise levels may be traded off for other qualities of the dwelling or the neighborhood. Research including different periods with a more and a less tight housing market may give insights into the relevance of housing market characteristics at the moment of residential choice. 
Yet another explanation might be that the noise-sensitive people who settled in high exposure areas did so because the higher noise levels were compensated for by lower prices for the dwellings. The (negative) correlation between house prices and noise levels is a well-known topic of study (see, for example, Nelson (1982) for one of the key studies in this area, or Navrud (2002) for a literature review). Research of Arsenio et al. (2006) in Lisbon yielded a correlation between income level and noise level. Noise sensitivity was not regarded in their research. Those with higher incomes and higher marginal values of noise tended to live in quieter apartments. This correlation was not further elaborated in this study due to a lack of relevant data. This may form a weakness in this research. On the other hand, one might argue that there is no reason at all why noise-sensitive people would be more willing to trade off high exposure for lower housing prices than the noise-insensitive people.

Another explanation could theoretically be that what is now a high exposure area was relatively quiet at the time of settling. However, from historical traffic data (AVV) it becomes clear that traffic intensities on the roadway passing by Maarssenbroek have increased by about $40 \%$ over a period of 20 years, the maximum residential period encountered in our research, equivalent to a rise in noise levels of about $1.5 \mathrm{~dB}$. In other words, traffic growth did not account for a large change in noise loads. What is noisy now was noisy 20 years ago as well.

\section{RECOMMENDATIONS}

Given the importance of noise sensitivity for the individual reactions on noise, it is recommended to pay more attention to noise sensitivity and other nonacoustical factors in future acoustical research. More questions on nonacoustical factors should be included in the national Dutch annoyance census (Franssen et al., 2004), carried out every five years or so. Inclusion in that census would give insight into the prevalence and spatial distribution of nonacoustical factors.

Noise sensitivity influences residential satisfaction. More information to prospective house owners/renters on the ambient noise levels and on one's noise sensitivity might prevent disappointment and could help to better match demand and supply on the housing market. A system of labeling dwellings according to their noise loads as well as labeling potential buyers according to personal noise sensitivity might be considered.

It is highly recommended to standardize the different noise-sensitivity scales. It would enhance comparability of future research on noise sensitivity.

Finally, because of the small sample size, external validity of this research is limited. Longitudinal surveys, larger samples and surveys in other areas (preferably where housing markets are less tight) are options for future research.

\section{ACKNOWLEDGMENTS}

We would like to thank Rebecca Stellato from Utrecht University for her statistical advice. Furthermore, we are grateful for the comments made by two anonymous reviewers which helped to improve the quality of the paper.

Arsenio, E., Bristow, A. L., and Wardman, M. (2006). "Stated choice valuations of traffic related noise," Transp. Res., Part D (11) 1, 15-31.

AVV (2003). "Verkeersgegevens, jaarrapport 2002" [Traffic data, annual report 2002], Rotterdam: Adviesdienst Verkeer en Vervoer.

Blauert, J. (1990). "Kognitive und ästhetische Aspekte von Lärmproblemen" [cognitive and aesthetic aspects of noise problems], Z. Lärmbekämpfung 38, 51-54. CBS www.cbs.nl/nl/cijfers/statline.

CBS (2003). "Gemeente op maat 2002; Maarssen." [Municipality measured 2002; Maarssen], Voorburg: Centraal Bureau voor de Statistiek.

Clark W. A. V. (1982). "Recent research on migration and mobility: A review and interpretation," Prog. Planning 1, 1-56.

Clark, W. A. V. and Dieleman, F. M. (1996). "Households and housing: Choice and outcomes in the housing market," New Brunswick (NJ): Center for Urban Policy Research, Rutgers the State University of New Jersey.

Clark, W. A. V., and Withers, S. (1999). "Changing jobs and changing houses: Mobility outcomes of employment transitions," J. Regional Sci. 39, 653-673.

Dutch Health Council (1994). Noise and Health, Report No. 1994/115, Den Haag.

Ellermeier, W., Eigenstetter, M., and Zimmer, K. (2001). "Psychoacoustic correlates of individual noise sensitivity," J. Acoust. Soc. Am. 109, 14641473.

European Commission (1996). "Green Paper on Future Noise Policy." Brussels: COM 96(540).

Fields, J. M. (1992). "Effect of personal and situational variables on noise annoyance: With special reference to implications for en route noise," Atlanta, Georgia Institute of Technology.

Fields, J. M. (1993). "Effects of personal and situational variables on noise annoyance in residential areas," J. Acoust. Soc. Am. 93, 2753-2763.

Flindell, I. H., and Stallen, P. J. M. (1999). "Non-acoustical factors in environmental noise," Noise and Health 3, 11-16.

Franssen, E. A. M., Dongen van, J. E. F., Ruysbroek, J. M. H., Vos, H., and Stellato, R. (2004). "Hinder door milieufactoren en de beoordeling van de leefomgeving in Nederland, Inventarisatie verstoringen 2003" [Noise annoyance and perceived environmental quality. Inventory 2003], RIVMreport 815120001, Bilthoven.

Gardner, J., Pierre, G., and Oswald, A. (2001). "Moving for job reasons," Mimeo, Department of Economics, University of Warwick.

Griendt, J. S. van de (2004). "Wonen in risicovolle situaties", [Living in risky situations], Haskoning, Utrecht.

Guski, R., Wichmann, U., Rohrmann, B., and Finke, H. (1978). "Konstruktion und Anwendung eines Fragebogens zur sozialwissenschaftlichen Untersuchung der Auswirkungen von Umweltlärm" [Construction and application of a questionnaire for social scientific research of the effects of ambient noise] Z. Sozialpsychologie 9, 50-65.

Guski, R. (1987). Lärm. Wirkungen unerwünschter Geräusche [Noise. Consequences of unwanted noise]. (Hans Huber, Bern.)

Guski, R. (1999). "Personal and social variables as co-determinants of noise annoyance," Environ. Behav. 32, 270-286.

Höger, R. (1999). "Theoretische Ansätze und Ergebnisse der psychologisch orientierten Lärmwirkungsforschung" [Theoretical principles and results of psychologically oriented research on the effects of noise], Umweltpsychologie 1, 6-20.

Housing Corporation (2004). "Who moves and where? A comparison of housing association tenants in London and northern regions," sector study 40.

Job, R. F. S. (1988). "Community response to noise: A review of factors influencing the relationship between noise exposure and reaction," J. Acoust. Soc. Am. 83, 991-1001.

Job, R. F. S. (1999). "Noise sensitivity as a factor influencing human reaction to noise," Noise Health 3, 57-68.

Kastka, J., and Noack, R. (1987). "On the interaction of sensory experience, causal attributive cognitions and visual context parameters in noise annoyance," in H. S. Koelega, Environmental Annoyance (Elsevier, Amsterdam), pp. 245-262.

Lako, J. V. (1987). "Geluidbelasting en migratie: Selectie-effecten bij onderzoek naar geluidbelasting en gezondheid, "[Noise load and migration: Selection-effects in a research of noise loads and health], Interfacultaire Vakgroep Energie en Milieukunde (IVEM-rapport No. 25).

Langdon, F. J. (1976). "Noise nuisance caused by road traffic in residential areas," J. Sound Vib. 47, 243-263. 
Leidelmeijer, K., and Marsman, G. (2001). "Beleving van de leefkwaliteit: Nadere analyses nulmeting Stad en Milieu" [Perception of quality of life: Further analyses starting point city and environment], Den Haag, Ministerie van VROM.

Lévy-Leboyer, C., and Moser, G. (1987). "Individual differences in noise annoyance: Four explanations," in H. S. Koelega, Environmental Annoyance (Elsevier), Amsterdam, pp. 293-297.

Michelson, W. (1980). "Long and short range criteria for housing choice and environmental behavior," J. Soc. Issues1052-0643 36, 135-149.

Miedema, H. M. E., and Vos, H. (1999). "Demographic and attitudinal factors that modify annoyance from transportation noise," J. Acoust. Soc. Am. 105, 3336-3344.

Miedema, H. M. E., and Oudshoorn, C. G. M. (2001). "Annoyance from transportation noise: Relationships with exposure metrics DNL and DENL and their concidence intervals and annoyance," Environ. Health Perspect. 109, 409-416.

Miedema, H. M. E., and Vos, H. (2003). "Noise sensitivity and reactions to noise and other environmental conditions," J. Acoust. Soc. Am. 113, $1492-1504$.

Milieudienst Noord-West Nederland (2000). "Integraal geluidonderzoek Maarssenbroek" [Integral noise survey Maarssenbroek], Milieudienst Noord-West Nederland, Breukelen.

Mulder, C. H., and Hooimeijer, P. (1999). "Residential relocations in the life course," in Population Issues, An interdisciplinary Focus (Plenum, New York).

Navrud, S. (2002). "The state-of-the-art on economic valuation of noise," final report to European Commission DG Environment.

Nelson, J. P. (1982). "Highway noise and property values: A survey of recent evidence," J. Transp. Econ. Policy 16, 117-138.

Ohrstrom, E. (1995). "Effects of low levels of road traffic noise during the night: A laboratory study on number of events, maximum noise levels and noise sensitivity," J. Sound Vib. 179, 603-615.

Owen, D. (1992). "Migration and employment," in Migration Processes and Patterns (Belhaven Press, 205-224), Vol. 2.

Rohrmann, B. (1986). "Environmental stressors and housing decisions review," Darmstadt: Bericht Nr. 86-2, Institut für Psychologie der THD.

Rohrmann, B. (1991). "The influence of noise on housing decisions," in Contributions to Psychological Acoustics (V), Oldenburg, Germany: Bibliotheks- und Informationssystem der Universität Oldenburg (BIS) pp. $75-86$.
Rossi, P. H. (1955). Why families move: A study in the social psychology of urban residential mobility (Free Press, New York).

Schümer-Kohrs, A., and Schümer, R. (1974). "Der sozialwissenschaftliche Untersuchungsteil" [The social scientific research part] in $D F G$ Forschungsbericht Fluglärmwirkungen (Boleat, Boppart, Germany).

Stallen, P. J. M. (1999). "A theoretical framework for environmental noise annoyance," Noise Health 3, 69-79.

Stansfeld, S. (1992). "Noise, noise sensitivity and psychiatric disorder: Epidemiological and psychophysiological studies," Psychol. Med. 15, 243260.

Stansfeld, S. A., Clark, C. R., Jenkins, L. M., and Tarnopolsky, A. (1985). "Sensitivity to noise in a community sample. I. The measurement of psychiatric disorder and personality," Psychol. Med. 15, 243-254.

Stansfeld, S. A., Sharp, D., Gallacher, J., and Babisch, W. (1993). "Road traffic noise, noise sensitivity and psychological disorder," Psychol. Med. 23, 977-985.

Stansfeld, S. A., Gallacher, J., Babisch, W., and Shipley, M. (1996). "Road traffic noise and psychiatric disorder: Prospective findings from the Caerphilly study," Br. Med. J. 313, 266-267.

Staples, S. L. (1996). "Human response to environmental noise: Psychological research and public policy," Am. Psychol. 51, 143-150.

Taylor, S. M. (1984). "A model of aircraft noise annoyance," J. Sound Vib. 96, 243-260.

Topf, M. (1985). "Noise-induced stress in hospital patients: Coping and nonauditory health outcomes," J. Human Stress 11, 125-134.

van Kamp, I., Job, R. F. Soames, Hatfield, J., Haines, M., Stellato, R. K., and Stansfeld, S. A. (2004). "The role of noise sensitivity in the noiseresponse relation: A comparison of three international airport studies," J. Acoust. Soc. Am. 116(6), 3471-3479.

Weinstein, D. (1978). "Individual differences in reactions to noise: A longitudinal study in a college dormitory," J. Appl. Psychol. 63, 458-466.

Zimmer, K., and Ellermeier, W. (1998a). "Konstruktion und Evaluation eines Fragebogens zur Erfassung der individuellen Lärmempfindlichkeit" [construction and evaluation of a questionnaire for the assessment of individual noise sensitivity], Diagnostica 44, 11-20.

Zimmer, K., and Ellermeier, W. (1998b). "Ein Kurzfragebogen zur Erfassung der individuellen Lärmempfindlichkeit" [a short list to register one's individual noise sensitivity], Umweltpsychologie 2, 54-63.

Zimmer, K., and Ellermeier, W. (1999). "Psychometric properties of four measures of noise sensitivity: A comparison," Environ. Psychol. 19, 295302 